\title{
Aabenraaskibes sejlads på Middelhavet omkring år 1800
}

\author{
Af Hans Chr. Johansen
}

Skibe fra hertugdømmernes købstæder nåede i 1700-tallet oftest længere omkring end deres søstre i Kongeriget. Aabenraa-skibene sejlede i særlig grad på Middelhavet. Professor, dr.oecon. Hans Chr. Johansen forklarer her, hvorfor denne sejlads fik en sådan dominans, $\mathrm{og}$ han belyser sejladsernes forløb og organisering $\mathrm{i}$ årtierne frem mod år 1800.

\section{Dansk langturssøfart - en "nicheproduktion«}

Gennem det meste af det 18. århundrede var international skibsfart udsat for en meget omfattende flagdiskrimination. De fleste lande prøvede at sikre de mest lønnende transporter over verdenshavene for egne skibe for derved i god merkantilistisk ånd at fremme beskæftigelse og rigdom i landet og at undgå at bruge fremmed valuta.

Det mest kendte eksempel på denne politik er de engelske navigationsakter, der bestemte, at transporter mellem det britiske riges forskellige dele skulle foregå på egne skibe, og at transporter mellem Storbritannien og udlandet kun kunne foregå på britiske skibe eller skibe fra det land, hvorfra varerne kom, eller hvortil de var bestemte. Det betød, at nogle af det 18. århundredes mest ekspanderende skibsruter, f.eks. den vigtige transport af kolonivarer til England og forsyningerne af den industrielle revolutions nye fabrikker med råvarer fra bl.a. Østersøområdet var lukket for tredjelandes fartøjer.

Lignende foranstaltninger blev truffet af en række andre lande, og resultatet var derfor, at det for lande uden en væsentlig im- eller eksport og uden større koloniområder var meget vanskeligt at opbygge en handelsflåde af betydning.

Det danske monarki befandt sig delvist $i$ en sådan situation. Man kunne nok gennem beskyttelsesforanstaltninger sikre, at den interne handel foregik på egne skibe, og det gav muligheder for en ikke uvæsentlig kystsejlads til Norge og Island samt for at forbeholde de årlige transporter af sukker fra de tre små vestindiske øer til moderlandets raffinaderier for egne skibe. Men monarkiets eksportindtægter kom først og fremmest fra Norge, som hvert år sendte store mængder fisk og træ til Vesteuropa, og det foregik i det væsentlige med norske og udenlandske skibe. Importen bestod til gengæld hovedsagelig af bearbejdede varer, der kun fyldte lidt i forhold til værdien og derfor kun 
krævede få skibe. Ville rederne i monarkiets to øvrige hoveddele, Danmark og hertugdømmerne, opbygge en handelsflåde, der skulle besejle fjernere liggende havne, måtte de derfor oparbejde en art "nicheproduktion «, hvor de fandt frem til mere sekundære ruter, som ikke var underkastet national beskyttelse, men som alligevel kunne være lønnende - og dette måtte ofte ske $\mathrm{i}$ hård konkurrence med andre nationers skibe, navnlig de hollandske. Hollænderne havde længe haft et konkurrencemæssigt fortrin, som en del af den protektionistiske lovgivning $i$ andre lande netop havde været rettet imod.

Når det lykkedes skibe fra det danske monarki at finde sådanne huller $\mathrm{i}$ beskyttelsen, skyldtes det en blanding af individuelt initiativ og statslig assi-

Tabel 1: Nationalitetsfordelingen for skibe i fart mellem Østersolandene og Vesteuropa 1785

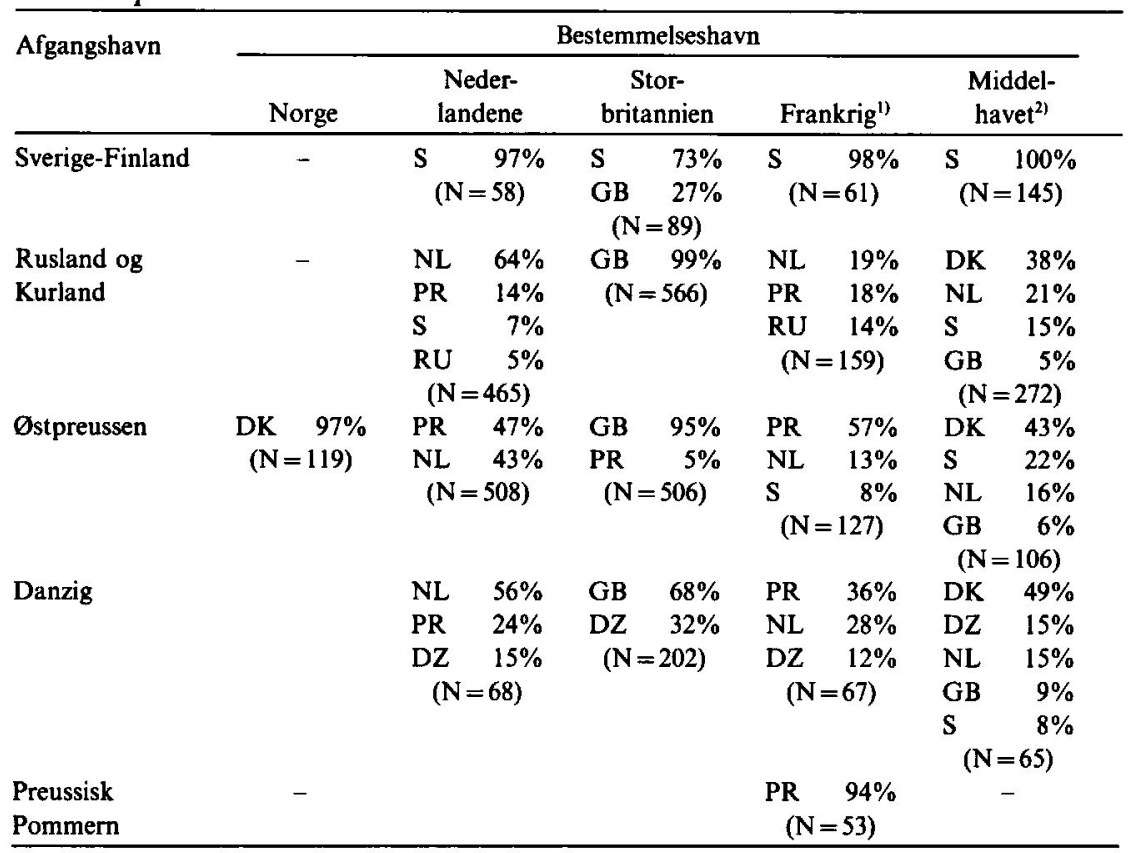

1) Frankrigs Kanal- og Atlanterhavskyst

2) Inclusive hele Spanien og Portugal

Note: Medtaget er ruter med mere end 50 passager i 1785 . Tallene i parentes angiver det samlede antal passager $\mathrm{i}$ årets løb. Procenttal er angivet for nationaliteter, hvis skibe udgjorde mindst $5 \%$ af passagerne på den pågældende rute. Der er anvendt følgende forkortelser for nationaliteterne: Det danske monarki (DK), Sverige, Finland og Svensk Pommern (S), Rusland og Kurland (RU), Preussen med Østpreussen og Ostfriesland (PR), Danzig (DZ), Nederlandene (NL), Storbritannien med Irland (GB).

Kilde: Edb-udgave af Øresundstoldregnskaberne 1784-95 på Odense Universitet. 
stance, og resultatet blev, at Danmark og hertugdømmerne i slutningen af det 18. århundrede havde en handelsflåde, der tilsammen var noget større end den norske, og at monarkiets samlede handelsflåde var den fjerdestørste i Europa, alene overgået af Storbritannien, Frankrig og Nederlandene.'

Et første indtryk af, hvilke ruter rederne dyrkede op for at vinde denne position, kan man få af Øresundstoldregnskabernes lister over skibe, der passerede Helsingør. Øresund var en flaskehals, hvorigennem en væsentlig del af Vesteuropas vareudveksling skete, og ruterne, der passerede Sundet, var derfor et oplagt emne for danske redere, der ønskede at komme ind på det internationale fragtmarked. Det var transporterne mod vest, der var de mest lønnende, fordi varehandelen den vej bestod af tunge råvarer, træ, korn, hør, hamp og jern m.m., mens den østgående trafik omfattede færdigvarer, der fyldte mindre $\mathrm{i}$ forhold til deres værdi. Mange skibe sejlede derfor ind $\mathrm{i}$ Østersøen i ballast.

Fra regnskaberne er $\mathrm{i}$ tabel 1 hentet tal for de vigtigste langvejsruter, der passerede Helsingør $i$ vestgående retning, med nationalitetsfordelingen for de registrerede skibe i 1785 .

I tabellen ses det tydeligt, hvorledes den diskriminerende søfartspolitik gav en ensidig nationalitetssammensætning i transporter til og fra Storbritannien, Sverige, Norge og Preussisk Pommern, hvorimod de åbne eksportområder har været Rusland, Kurland, Østpreussen og Danzig og de åbne destinationer Nederlandene, Frankrig og Sydeuropa.

\section{Middelhavssejlerne og deres hjemsted}

Skibe fra det danske monarki har her især kunnet gøre sig gældende i Middelhavsfarten. I transporterne til Holland og Frankrig er det i højere grad preussiske skibe og hollænderne selv, der har siddet på markedet. Men den danske Middelhavssejlads har - som det også kan ses af tabellen - ikke været uden konkurrence. Blandt andet hollændere og svenskere har også haft væsentlige markedsandele.

Ved en vurdering af den økonomiske betydning af transporterne på de forskellige ruter må det tages i betragtning, at skibene, der sejlede til Middelhavet, havde en længere sejltid og derfor indtjente mere fragt pr. passage ved Helsingør end skibe, der skulle til Holland og Storbritannien. For de sidstnævnte var det ikke ualmindeligt med to til tre returrejser $\mathrm{i}$ løbet af den årlige sejlsæson fra april til november.

Den betydelige danske sejlads på Middelhavet begynder omkring det 18 . århundredes midte og ekspanderer kraftigt helt frem til 1807, da Danmarks 


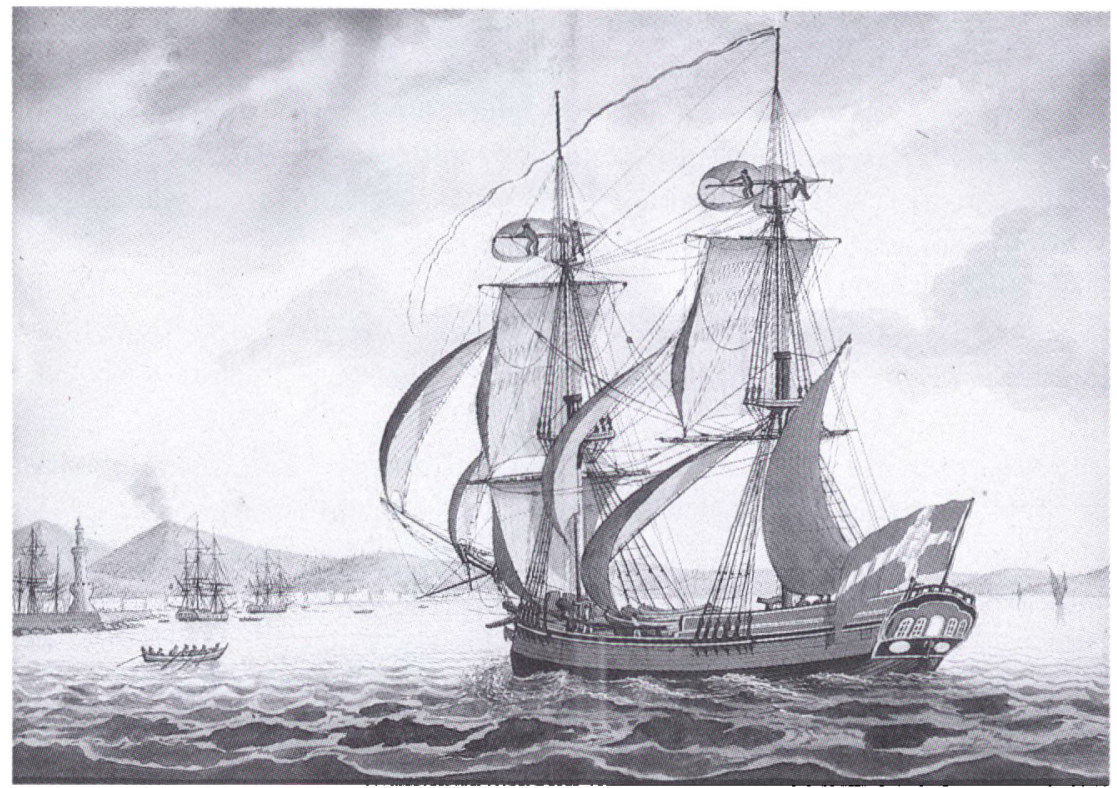

Brigantinen "Industriak af Aabenraa ud for Napoli med Vesuvi baggrunden. Billedet er malet i Aabenraa i 1799. Det var skibe af denne type, som dominerede $i$ sejladsen på Middelhavet. Aabenraa Museum.

inddragelse i Napoleonskrigene sætter en brat stopper for den danske handelsflådes virksomhed. ${ }^{2}$

Som forklaringer på, at dette fremstød kunne lykkes, har man især peget på to faktorer, nemlig den danske neutralitet under de europæiske storkrige efter 1750 - sejladsen skulle altså være en udpræget krigstidsspekulation og afslutningen af traktater med de nordafrikanske stater, der skærmede handelsflåden mod tidligere tiders mange overfald fra »barbareskernes« sørøverskibe.

Disse to faktorer er dog ikke en tilstrækkelig forklaring. For det første gælder det, at ekspansionen ikke er begrænset til krigsperioderne 1755-63, 1776-83 og efter 1792. Væksten i antallet af passager ved Helsingør er nok særligt stor i disse år, men i de mellemliggende år kunne danske skibe fastholde en væsentlig del af markedet og en større markedsandel end i den foregående fredsperiode. Det var kun i udprægede kriseår, f.eks. i 1770, at der skete en dramatisk nedgang $\mathrm{i}$ antallet af danske passager, men dette fald ramte også de nærmeste konkurrenter fra udlandet. Årsagen var en almindelig tilbagegang i efterspørgslen efter tonnage på grund af en nedgangskonjunktur. ${ }^{3}$

For det andet gælder det, at også Danmarks to nærmeste konkurrenter $\mathrm{i}$ Middelhavssejladsen, Nederlandene og Sverige, havde aftaler med sørøversta- 
terne, så deres skibe ligeledes uden fare kunne sejle ind i Middelhavet og i de tilgrænsende områder af Atlanterhavet, hvor sørøverskibene også huserede i perioder. $^{4}$

Der må derfor også have været danske konkurrencemæssige fortrin i omkostningsniveauet, som har medvirket til ekspansionen, men det er vanskeligt at finde kilder, som i dag kan dokumentere dette.

Det er derimod muligt at give et mere detaljeret billede af, hvilke kredse i det danske samfund, der udnyttede de muligheder, der lå i sejladsen mellem Østersøen og Middelhavet, og det følgende skal vise nogle særpræg, der vedrører den sønderjyske deltagelse i årene omkring år 1800.

Som et udgangspunkt kan vi se på, hvilke hjemsteder der blev opgivet af de 189 skippere fra det danske monarki, der i 1785 passerede Helsingør på vej til Sydeuropa. Derved forstås $i$ det følgende Middelhavets kyster samt spanske og portugisiske havne ved Atlanterhavet.

Fordelingen er følgende:

København ............... 30 passager

Andre danske havne $\ldots \ldots \ldots \ldots \ldots \ldots \ldots$. 8 passager

Flensborg $\ldots \ldots \ldots \ldots \ldots \ldots \ldots \ldots \ldots 67$ passager

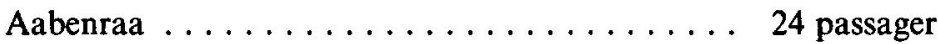

Altona .................. 12 passager

Andre havne $\mathrm{i}$ hertugdømmerne $\ldots \ldots \ldots \ldots .25$ passager

Norske havne ................. 23 passager

Sammenlignes denne fordeling med hjemstederne for monarkiets samlede handelsflåde er det påfaldende så få norske skibe, der er med. Det skyldes dog ikke, at der ikke optrådte norske skibe i Middelhavet, tværtimod. Det kan ses af antallet af såkaldte algierske sopas, ${ }^{5}$ der blev udstedt i 1785 til sejlads til Sydeuropa. Deres fordeling var nemlig følgende efter skibenes hjemsteder:

København .................. 62 søpas

Andre danske havne .............. 13 søpas

Flensborg . . . . . . . . . . . . . 67 søpas

Aabenraa . . . . . . . . . . . . . 26 søpas

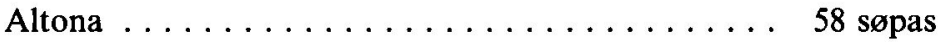

Andre havne i hertugdømmerne . . . . . . . 28 søpas

Norske havne . . . . . . . . . . . . . . . . 107 søpas

De norske skibe sejlede imidlertid med norske varer, fortrinsvis fisk til Middelhavslandene, og de behøvede derfor ikke omvejen til en baltisk havn for at få den udgående last og optræder følgelig heller ikke ved Helsingør. Sammenlignes tallene fra de to kilder, ses det, at også flertallet af Altonaskibe løste pas 
uden at passere Øresund. Konsulatsindberetninger fra Middelhavslandene viser, at de som oftest ankom med en ladning fra Hamburg.

Hjemstedsfordelingen for skibene fra Danmark og hertugdømmerne er ikke overraskende på de tre første pladser. København med en handelsflåde på ca. 28.000 kommercelæster, Flensborg med ca. 9.000 kommercelæster og Altona med ca. 14.000 kommercelæster var de tre største havnebyer og langt større end de øvrige $i$ området. Mere overraskende er Aabenraas stærke position. Denne by havde ganske vist altid været en betydningsfuld havneby, men netop sidste halvdel af det 18. århundrede beskrives normalt som en nedgangstid for Aabenraaskibsfarten, et mellemspil mellem første halvdel af det 18. århundrede med en handelsflåde på omkring 4.000 kommercelæster, der blandt andet var beskæftiget i farten mellem Sverige og England, men blev skadet af engelske og svenske protektionistiske foranstaltninger midt $\mathrm{i}$ århundredet, og den store ekspansion $\mathrm{i}$ det 19. århundrede, hvor en så mægtig mand som rederen Jørgen Bruhn var med til at gøre Aabenraa til provinsens største havneby, der med en handelsflåde på ca. 5.000 kommercelæster i 1860erne endog overgik Flensborgs - i øvrigt med Middelhavet som et af de mere betydningsfulde mål for sejladserne. ${ }^{6}$

\section{Aabenraaskibe i Middelhavet}

Aabenraas afhængighed af Middelhavssejladsen i sidste halvdel af det 18. århundrede kommer også klart frem, hvis man sammenligner størrelsesfordelingen af byens handelsflåde med den, der fandtes $\mathrm{i}$ de to andre store skibsfartsbyer på Slesvigs østkyst, Flensborg og Sønderborg. Fra midten af 1790erne findes der bevaret skibslister fra alle tre byer, og de viser den i tabel 2 viste fordeling.

Tabel 2: Handelsfiaderne i Flensborg, Aabenraa og Sonderborg fordelt efter storrelse 1796

\begin{tabular}{cccc}
\hline & \multicolumn{3}{c}{ Antal skibe } \\
\cline { 2 - 4 } Størrelse & Flensborg & Aabenraa & Sønderborg \\
\hline $1-19$ komm.læster & 93 & 7 & 41 \\
$20-39$ komm.læster & 67 & 9 & 13 \\
$40-59$ komm.læster & 42 & 11 & 4 \\
$60-79$ komm.læster & 21 & 10 & 2 \\
$80-99$ komm.læster & 34 & 7 & 1 \\
$100-\quad$ komm.læster & 12 & - & - \\
\hline
\end{tabular}

Kilder: Stadtarchiv, Flensborg, A,319, Bd. 2; Landsarkivet, Aabenraa: Aabenraa byarkiv, Skibslister; Rigsarkivet: Udenrigsministeriet (kommercekollegiet), samlede sager 1762-1866, nr. 58, Vedr. skibsfarten i Slesvig og Holsten. 
Tabellen viser, at der var to størrelser skibe, der udgjorde tyngdepunktet $\mathrm{i}$ byernes og i øvrigt også i den øvrige handelsflåde i Danmark og hertugdømmerne. Den ene var et skib på omkring 20 kommercelæster, som især brugtes i kystsejladsen og til den meget omfattende sejlads med forsyninger til Norge og returlaster med træ. Sønderborgs handelsflåde er tydeligt specialiseret til denne sejlads, men den har tillige spillet en stor rolle for mange Flensborgskippere og er også velkendt fra de fleste danske provinsbyers handelsflåder. Den anden skibstype er på 50-100 kommercelæster, et ganske stort skib efter samtidens forhold, kun skibene på sejladserne til Det fjerne Østen var væsentligt større. Denne skibsstørrelse blev først og fremmest brugt til sejlads på Vest- og Sydeuropa. Tabel 2 viser, hvor specialiseret Aabenraa var i denne type af skibe, mens man i Sønderborg kun i få tilfælde havde anskaffet skibe, der var store nok til at vove sig vest for Skagen. I Flensborg havde man derimod skibe både af den lille og den store type og kunne altså deltage $\mathrm{i}$ mange forskellige former for transporter.

Aabenraas særpræg gør det naturligt at se lidt nærmere på skibenes anvendelse. I perioden fra 1784 til 1807 bestod handelsflåden af omkring 30-40 skibe på over 30 kommercelæster og et fåtal mindre. Et indtryk af sejladsmønstret kan fås ved at følge et af skibene gennem perioden, nemlig brigantinen $\mathrm{Pa}$ tientia $^{7}$ på 62 kommercelæster bygget i Kalmar i 1761. Fra 1789 bærer den i stedet navnet Fortuna. Kaptajn var fra 1784 til 1797 P.J. Thomsen, derefter Magnus Fischer og omkring 1805 Conrad Boysen.

Øresundstoldregnskaberne beretter om følgende passager for skibet mellem 1784 til 1806:

1. aug. 1784 fra Riga til Oporto med hør, hamp og blår

5. dec. 1784 fra Setubal til København med salt og sydfrugter

22. jul. 1785 fra Riga til Livorno med hør

12. aug. 1786 fra Bremen til Aabenraa med eddike, jern og papir

27. jun. 1788 fra Pernau til Lissabon med hør

15. nov. 1788 fra Setubal til København med salt

18. jun. 1790 fra Pillau til Le Havre med hvede

12. maj 1791 fra Hamburg til Riga i ballast

19. jul. 1791 fra Riga til Maas med hørfrø

29. maj 1792 fra Pillau til Barcelona med hvede

27. apr. 1794 fra Messina til St. Petersborg med sydfrugter, vin og olivenolie

11. okt. 1795 fra Riga til Carril med hør og hamp

4. jul. 1797 fra Riga til Spanien med hør

3. aug. 1798 fra Pernau til Oporto med hør

23. jul. 1800 fra Riga til Livorno med hør

25. sep. 1802 fra Villanova til St. Petersborg med vin og kork

22. jul. 1803 fra Riga til Carril med hør

27. sep. 1804 fra Emden til Østersøen i ballast

14. jul. 1805 fra Riga til Riwadeo med hør

31. maj 1806 fra Bremen til Østersøen i ballast 


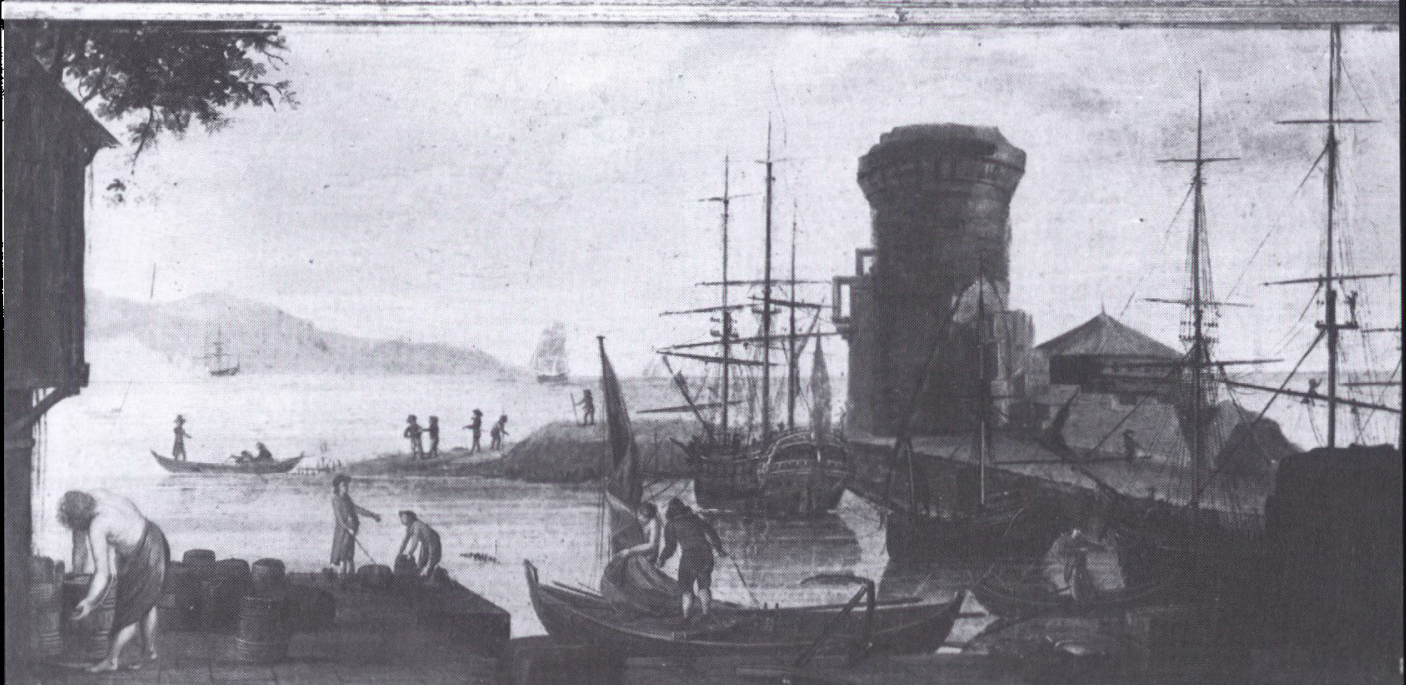

Aabenraa-skibene var i sarlig grad afhangige af sejlads på Middelhavet, og sydlandske landskaber virkede derfor ikke fremmede for sefolk og skibsredere i Aabenraa. Jes Jessen har malet ikke så få billeder med motiv fra Middelhavslandene. Her en havn med kastel fra 0. 1790. I havnebassinet to tremastede skibe og flere mindre bade. I forgrunden tonder og baller. Billedet har tidligere hangt hos sejlmagermester og skibsreder Jergen Cornett i Aabenraa. Historiske Samlinger, Aabenraa.

Listen over skibets sejladser, som den fremgår af disse passager, er ikke fuldstændig. Der mangler tydeligvis en del retursejladser fra Sydeuropa. Formodentlig er skibet da passeret igennem Lillebælt og har været på et kortere eller længere ophold i Aabenraa. Sammenligninger med udstedelsen af søpas til skibet viser også, at de er løst i 1784, 1785, 1788, 1791, 1792, 1794, 1795, $1797,1798,1800,1802,1803,1805$ og 1806. Det tyder på, at rejsen til Maas i 1791 er blevet forlænget til Sydeuropa, og at skibet i 1794 og 1802 er afgået til Sydeuropa uden først at have været i Østersøen for at finde en ladning til udrejsen.

Trods disse mangler kan man alligevel få et billede frem ved at studere toldlisterne. Skibet har normalt passeret Helsingør for vestgående midt på sommeren efter først at have været i den østlige Østersø, hyppigst i Riga. Hvis turen er udgået fra Aabenraa, kan man med datidens sejltider regne med, at hjembyen er blevet forladt ca. to måneder forinden passagen gennem Sundet, dvs. i april eller maj, og det passer også med, at søpassene normalt er dateret omkring denne tid på året. Tidligt i perioden synes det at have været almindeligt, at mange Aabenraaskibe kom tilbage fra Sydeuropa omkring årsskiftet, 
og besætning og skib har da kunnet overvintre hjemme. Der er imidlertid også adskillige eksempler, der tyder på, at skibet er blevet i Sydeuropa vinteren igennem og somme tider endnu længere. Det er da først vendt tilbage, når vinterstormene $\mathrm{i}$ de nordeuropæiske farvande ikke længere udgjorde en fare for skibet. ${ }^{8}$ Om et andet af Aabenraaskibene "Frau Maria Helsingør den 8 . august 1785 på rejse fra St. Petersborg til Lissabon med jern, hør, hamp og blår om bord, oplyser konsulatsindberetningerne ${ }^{9}$ således, at skibet i vinteren 1785/86 bl.a. anløb Lissabon, Cadiz, Malaga og Alicante, og søpasset fra denne tur blev først leveret tilbage til kommercekollegiet $\mathrm{i}$ august 1786. Efter 1800 bliver denne form for sejlads mere almindelig, men tilpasningen til vintersejlads i Middelhavet sker ret sent for Aabenraas vedkommende. De større danske skibsfartsbyer havde allerede tidligere ladet størstedelen af de store skibe gå i trampfart mellem havne i Middelhavsområdet $\mathrm{i}$ vinterhalvåret for på den måde at forlænge sæsonen og forbedre indtjeningen.

Et mere fuldstændigt billede af udviklingen i de sydeuropæiske sejladsers betydning for Aabenraaskibenes vedkommende fås af tabel 3 på næste side.

I alle år er de dominerende destinationer for skibene at finde i Portugal, Spanien, Sydfrankrig og Italien, og skibene har som hovedregel først været i Østersøen efter last, før de begav sig sydpå. Hvis en del af skibene er blevet i Middelhavet et stykke ind i det efterfølgende år, ses det, at det ofte kun har været få af de store Aabenraaskibe, der har været beskæftiget på andre ruter.

Der er dog kraftige bølgebevægelser i antallet. Det ses således, at næsten ingen skibe tog af sted i 1787, og skibslisten for Aabenraa oplyser ved 11 af skibene, at de ikke har sejlet i dette år. Hvad årsagen hertil kan have været, er vanskeligt at sige. Der er generelt færre skibe fra Danmark i Sydeuropa i 1787, men nedgangen er langt mindre udtalt for både Københavns og Flensborgs vedkommende.

I 1789-90 overgik en del Aabenraaskibe til sejlads mellem svenske havne. På grund af den svensk-russiske krig var den svenske handelsflåde lammet, og den svenske regering lempede derfor på de stramme nationalitetsregler. I et enkelt tilfælde foretog et Aabenraaskib endog sejlads med varer fra Göteborg til St. Petersborg, dvs. fra den ene krigsførende part til den anden.

I 1790 flyttes en del skibe også til at transportere korn til Frankrig, som på grund af misvækst i 1789 var stor kornimportør, og nedgangen omkring 1801 står i forbindelse med de udenrigspolitiske forhold. Samtidig med englændernes angreb på København (slaget på Rheden) blev mange danske skibe opbragt og kom efter frigivelsen først hjem sent på året med ødelagte ladninger. Det tog nogen tid at få dem udrustet igen, og måske har man også været noget forsigtig med at udsende skibene, indtil der var mere klarhed over den udenrigspolitiske udvikling. 
Tabel 3: Aabenraas skibe over 30 kommercelaster og deres sejlads på Sydeuropa 1784-1806

\begin{tabular}{lccc}
\hline & \multicolumn{2}{c}{ Antal skibe i } \\
\cline { 2 - 4 } Ar & Skibslisten & $\begin{array}{c}\text { søpas- } \\
\text { protokollerne }\end{array}$ & $\begin{array}{c}\text { Oresundstoldregnskaberne med } \\
\text { Sydeuropa }\end{array}$ \\
\hline 1784 & 39 & 27 & 25 \\
1785 & 40 & 27 & 23 \\
1786 & 38 & 20 & 19 \\
1787 & 37 & 1 & 2 \\
1788 & 37 & 20 & 20 \\
1789 & 38 & 11 & 9 \\
1790 & 38 & 22 & 22 \\
1791 & 37 & 12 & 12 \\
1792 & 37 & 23 & 22 \\
1793 & 34 & 27 & 21 \\
1794 & 33 & 20 & 16 \\
1795 & 35 & 25 & 11 \\
1796 & 36 & 24 & 17 \\
1797 & 36 & 18 & 14 \\
1798 & 37 & 20 & 16 \\
1799 & 33 & 16 & 12 \\
1800 & 34 & 18 & 16 \\
1801 & 31 & 9 & 7 \\
1802 & 31 & 12 & 8 \\
1803 & 35 & 26 & 18 \\
1804 & 33 & 13 & 13 \\
1805 & 31 & 18 & 15 \\
1806 & 31 & 15 & 9 \\
\hline$N 06$ & 31 & & 12 \\
\hline
\end{tabular}

Note: Der er kun medtaget skibe, der er identificeret i skibslisterne for Aabenraa med en tonnage på over 30 kommercelæster. Det gennemgåede materiale tyder på, at yderligere et par Aabenraaskibe har været i Middelhavet i perioden, men at disse har været i Aabenraabesiddelse $\mathrm{i}$ under et år, eller at de kun har været delvist Aabenraaejet. Der er i perioden også et par eksempler på, at skibe med en mindre tonnage har været $i$ Middelhavet.

Kilder: Landsarkivet, Aabenraa: Aabenraa byarkiv, Skibslister; Rigsarkivet: Kommercekollegiet, søpasprotokoller; edb-udgave af Øresundstoldregnskaberne på Odense Universitet.

Tabel 4: Fordelingen af passager $i$ Øresund destineret for Sydeuropa og udstedte sopas 1805 efter skibenes hjemsteder

\begin{tabular}{lcc}
\hline & \multicolumn{2}{c}{ Antal skibe } \\
\cline { 2 - 3 } Hjemsted & Passager & Søpas \\
\hline København & 37 & 76 \\
Andre danske havne & 12 & 26 \\
Flensborg & 45 & 67 \\
Aabenraa & 15 & 18 \\
Altona & 9 & 54 \\
Andre havne i hertugdømmerne & 15 & 38 \\
Norske havne & 18 & 265 \\
\hline
\end{tabular}

Kilder: Edb-udgave af Øresundstoldregnskaberne; Rigsarkivet: Kommercekollegiet, søpasprotokoller. 
Tabel 5: Udskiftningen af de storre skibe $i$ Aabenraas handelsfladde 1784-1806

\begin{tabular}{lcccccc}
\hline & \multicolumn{6}{c}{ Antal skibe } \\
\cline { 2 - 6 } Ar & Tilgang & forlis & salg & ophugning & kapring & $\begin{array}{c}\text { Netto- } \\
\text { tilgang }\end{array}$ \\
\cline { 2 - 7 } $1785-89$ & 6 & 3 & 4 & & - & -1 \\
$1790-94$ & 3 & 8 & 3 & - & - & -8 \\
$1795-99$ & 15 & 5 & 4 & 2 & 2 & 2 \\
$1800-04$ & 8 & 5 & 7 & 1 & - & -5 \\
$1805-06$ & 4 & & 3 & & & 1 \\
Ialt & 36 & 21 & 21 & 3 & 2 & -11 \\
\hline
\end{tabular}

Note: Medtaget er skibe på mindst 30 kommercelæster. Tabellens tal stemmer ikke fuldt ud med bevægelserne i bestanden i tabel 3. Det skyldes, at forlisene først medfører, at skibene bliver slettet af skibslisten, når forliset er blevet bekendt for myndighederne i Aabenraa.

Kilde: Landsarkivet, Aabenraa: Aabenraa byarkiv, Skibslister.

Efter 1801 kom Aabenraaskibsfartens sejlads på Sydeuropa - bortset fra i 1803 - ikke op på helt de samme tal som tidligere, men noget af nedgangen i antallet af passager skyldes dog, at skibene blev længere tid i Middelhavet. Set $i$ et nationalt perspektiv havde Aabenraa imidlertid mindre betydning efter år 1800 end i 1780erne. Tal for antal passager og antal udstedte søpas til Sydeuropa i 1805 er vist i tabel 4. Sammenligner man denne med listen for 1785 ovenfor, er det tydeligt, at Aabenraa har mistet terræn.

Tabel 3 viser også, at der må have været andre ruter, der nu spillede en rolle for Aabenraaskibene. Skibene deltog f.eks. i forsyningerne af det nordlige Norge (Finmarken), og der er flere eksempler på, at Aabenraaskibe søgte til Arkhangelsk for at finde fragter.

De vanskeligere tider for Aabenraaflåden efter århundredskiftet viser sig også ved en del salg af skibe. I tabel 5 ses ændringerne i bestanden mellem 1784 og 1806. Antallet af skibe på mindst 30 kommercelæster blev i løbet af perioden reduceret med omkring en fjerdedel.

I 1780erne og 1790erne var det især gennem forlis, at flåden blev reduceret, og ofte var det totalforlis, som kostede hele besætningen livet. Skibslisterne meddeler lakonisk: "Forsvundet efter afgang fra Dover februar 1785« eller "forulykket ved Algarve i februar 1788«. I nogle tilfælde slap man med strandinger, og kaptajnen optræder igen som fører af et skib senere, men skibet gik normalt tabt.

Frem til 1807 var Aabenraarederne relativt heldige med at undgå fremmede kaperskibe, selv om ruterne til Sydeuropa under revolutions- og Napoleonskrigene gik gennem farvande, hvor de krigsførende magters flåder og kapere huserede. Kun i 1798 led man tab, da to skibe "Neptunus« på $39 \mathrm{kml}$. og "St. Johannes« på $37 \mathrm{kml}$. blev opbragt af franske skibe. 
Krigsudbruddet i 1807 blev derimod en katastrofe for Aabenraa. Da myndighederne $\mathrm{i}$ byen efter det første krigsår skulle indsende den årlige skibsliste til kommercekollegiet, tilføjede de oplysninger om, hvor skibene befandt sig. Flåden bestod da af 33 skibe på mindst $30 \mathrm{kml}$. Om dem anføres det, at ni er opbragt af englænderne, to er blevet beslaglagt af andre krigsførende nationer, otte ligger indespærret i sydeuropæiske havne og to i Østersøhavne. De sidste 12 »ligger stille« i Norge, København og den slesvig-holstenske kanal.

Periodens tilgang af skibe, der var særlig stor i slutningen af $1790 \mathrm{erne}$, kom dels fra køb, dels fra nybyggeri. Det sidste havde særlig betydning fra omkring 1794, hvor mange af de nye skibe blev bygget i Aabenraa.

\section{Aabenraaflådens bemanding og finansiering}

Aabenraa havde omkring $1800 \mathrm{ca} .2 .800$ indbyggere, hvoraf knap en tredjedel var mænd i alderen fra 14 til 60 år, dvs. i de aldersklasser, hvorfra skibsbesætningerne kunne rekrutteres. Hvert af de store skibe havde mellem 8 og 12 mands besætning, mens de mindre kunne nøjes med 4-5 mand. Det betød, at

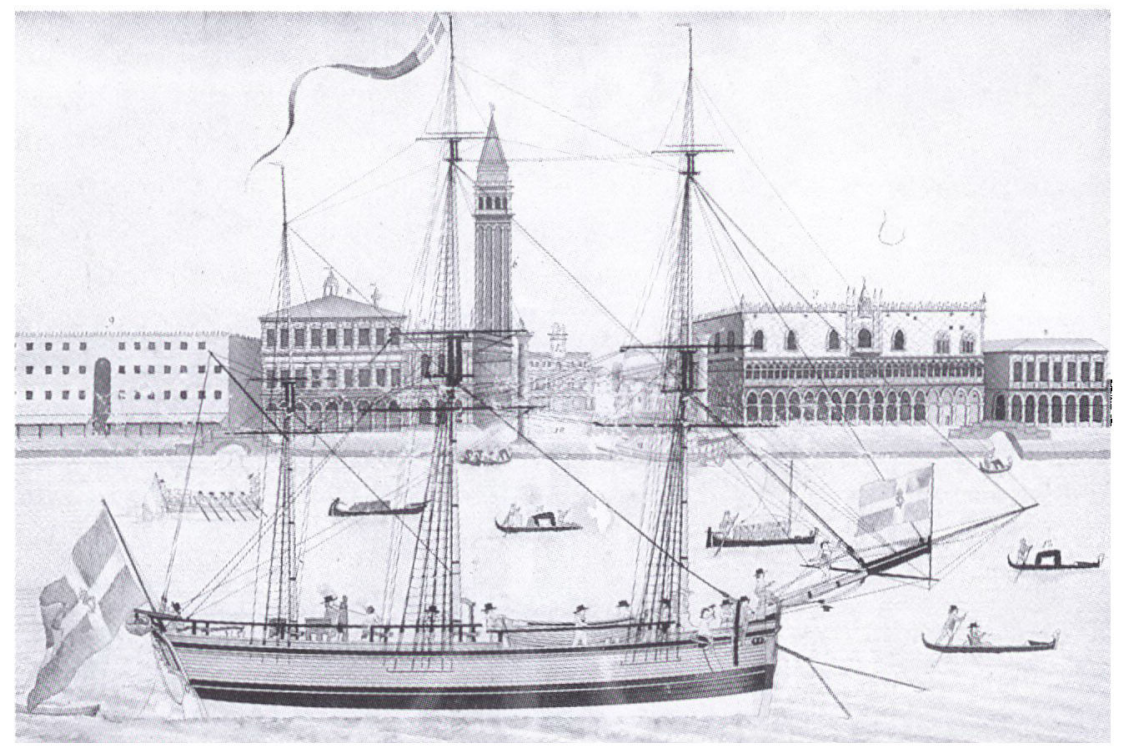

Fuldskibet "Die Hoffnung" af Aabenraa ud for Venedig ca. 1790. Kaptajn var Martin Bahnsen. Fuldskibe eller fregatter var tidens storste skibe. Skibet her var pd 86 kommercelaster. Aabenraa Museum. 
der i slutningen af det 18. århundrede krævedes omkring 450 mand for, at hele flåden kunne være sejlklar. Set i forhold til folketallet ville det have været en voldsom åreladning af byen, hvis alle søfolk havde været hentet fra byens borgere - omkring halvdelen af alle voksne erhvervsaktive mænd. Det var dog heller ikke tilfældet. Mange kom fra byens nærmeste omegn, bl.a. rekrutteredes en del fra Løjt sogn, ${ }^{10}$ og flere navne på kaptajner og styrmænd tyder også på en tilknytning til fjernere liggende steder.

Det har også været en betydelig økonomisk investering for Aabenraa at kunne have en så stor handelsflåde. Et skib af den type, som Aabenraarederne typisk anvendte, kostede i 1780erne 5. $10.000 \mathrm{rdl}$. at bygge. Det betyder, at den samlede kapital, der var investeret i flåden, må have beløbet sig til omkring 200.000 rdl. Til sammenligning kan det nævnes, at et mindre beboelseshus havde en værdi på omkring 200 rigsdaler, og at velstående håndværkere havde en årsindkomst på 100-200 rigsdaler.

Mens flåderne i Altona og Flensborg typisk var ejet af storredere, var forholdene helt anderledes i Aabenraa. I Altona ejede de fem største redere således omkring $3 / 4$ af byens skibe. I Flensborg var antallet af redere en del større, men også der dominerede en mindre gruppe personer rederlisterne. I Aabenraa var der derimod en meget betydelig spredning af ejendomsretten til skibene. Det normale var, at hvert skib var opdelt i 10-20 anparter. I skibslisten for 1789 er der således opgivet navne på ejere af næsten 500 anparter. Det oplyses ikke, om hver anpart $i$ et skib var lige stor, men det er det mest sandsynlige vurderet ud fra forholdene andre steder.

Anparterne er delt ud på knap 200 navne, og det hyppigste er, at anpartsejerne kun står opført ved et, to eller tre skibe. Kun 26 navne er opført med mindst fem anparter - den største skibsejer har 19 anparter, og det er et dødsbo, så man må antage, at der kort tid efter er sket en spredning af denne samling.

De største anpartsejere findes blandt byens købmænd og dermed blandt Aabenraas rigeste borgere, som det kan ses af tabel 6. Hvis den gennemsnitlige anpart har haft en værdi på ca. 500 rdl., er det kun en mindre del af købmændenes formue, der har været investeret direkte i skibene.

I øvrigt omfatter kredsen af anpartsejere som oftest kaptajnerne på skibene, hyppigt blot med en enkelt anpart, samt kredse uden for byen, blandt disse også Løjtbønderne, hvis sønner kom ud at sejle med skibene. I mange tilfælde tyder navnene på anpartsejerne på familieskab mellem flere ejere af samme skib. I 1789 er der f.eks. seks personer, der hedder Koch til efternavn, deriblandt købmanden nævnt i tabel 6 på næste side, seks, der hedder Bruhn, fire med efternavnet Wissing og fire ved navn Kopperholdt.

Det er også karakteristisk, at der er mange enker blandt anpartsejerne, 
Tabel 6: Aabenraas rigeste købmand $i 1789$ og deres engagement $i$ skibsfarten.

\begin{tabular}{lcc}
\hline & $\begin{array}{c}\text { Selvangivet } \\
\text { formue }\end{array}$ & $\begin{array}{c}\text { Antal } \\
\text { skibsanparter }\end{array}$ \\
\hline Johan Heysel & $14.000 \mathrm{rdl}$ & 7 \\
Jurgen Iwersen & $14.000 \mathrm{rdl}$. & $15^{11}$ \\
J.F. Biørnsen & $8.300 \mathrm{rdl}$. & 9 \\
Jurgen Koch & $8.000 \mathrm{rdl}$. & 11 \\
Niels Thomsen & $8.000 \mathrm{rdl}$ & 9 \\
\hline
\end{tabular}

1) Heraf er 10 opgivet som tilhørende Jurgen Iwersen og 5 som tilhørende Jurgen Iwersens enke. Kilder: Landsarkivet, Aabenraa: Aabenraa byarkiv, Skibslister og Formue- indtægts- og næringsskatten 1789.

formodentlig et bidrag til forsørgelsen af de ældre efterladte efter kaptajner, købmænd og bønder i byens omegn.

Den daglige administration af skibenes bevægelser er næppe blevet varetaget af hele ejerkredsen. I søpasprotokollerne står under rubrikken "Rhederens navn« normalt kun opført et eller to navne, og det er som oftest købmænd eller kaptajnen selv. I 1788-89 er købmandene J.F. Biørnsen og M. Jebsen anført med hver syv skibe og Niels Thomsen med fem.

Disse personer har da formodentlig stået for at slutte aftaler med københavnske eller udenlandske købmand om de sejladser, der skulle foretages. I trafikken mellem Østersøen og Sydeuropa har sådanne aftaler ofte kunnet omfatte flere skibe. Det viser sig bl.a. ved, at der blev anskaffet søpas til flere skibe samtidig, og denne gruppe af skibe toldbehandles et par måneder senere på samme dag eller over et par dage i Helsingør med en ensartet ladning og på samme rute. Først når skibene nåede Lissabon eller en anden sydeuropxisk havn, skiltes deres veje, og de søgte hver især at finde nye fragter enten ind $i$ Middelhavet eller tilbage til Østersøen.

Et eksempel på sådanne gruppesejladser, der nok har varet følt som en måde, hvorpå man kunne hjælpe hinanden i tilfælde af forlis eller andre problemer, kan man f.eks. finde i 1786. Fra den 15. til den 19. juni dette år angiver Øresundstoldregnskaberne, at Aabenraaskibene Die Einigkeit (kaptajn Christian Richelsen), Frau Susanne (Nis Bruhn), Die Hoffnung (Jes Eschelsen), Maria Catharina Galley (P.T. Hubschman), Constantia (Mich. Jebsen), Industria (Frederich Callesen), St. Marcus (Joh. Chr. Jebsen) og Anna Maria (Lave Festersen) passerede Helsingør på vej fra Memel til Lissabon, alle med bjælker om bord. Skibene repræsenterede flere forskellige hovedredere, hvilket tyder på et samarbejde på tværs af den enkelte Aabenraareders særinteresser. 


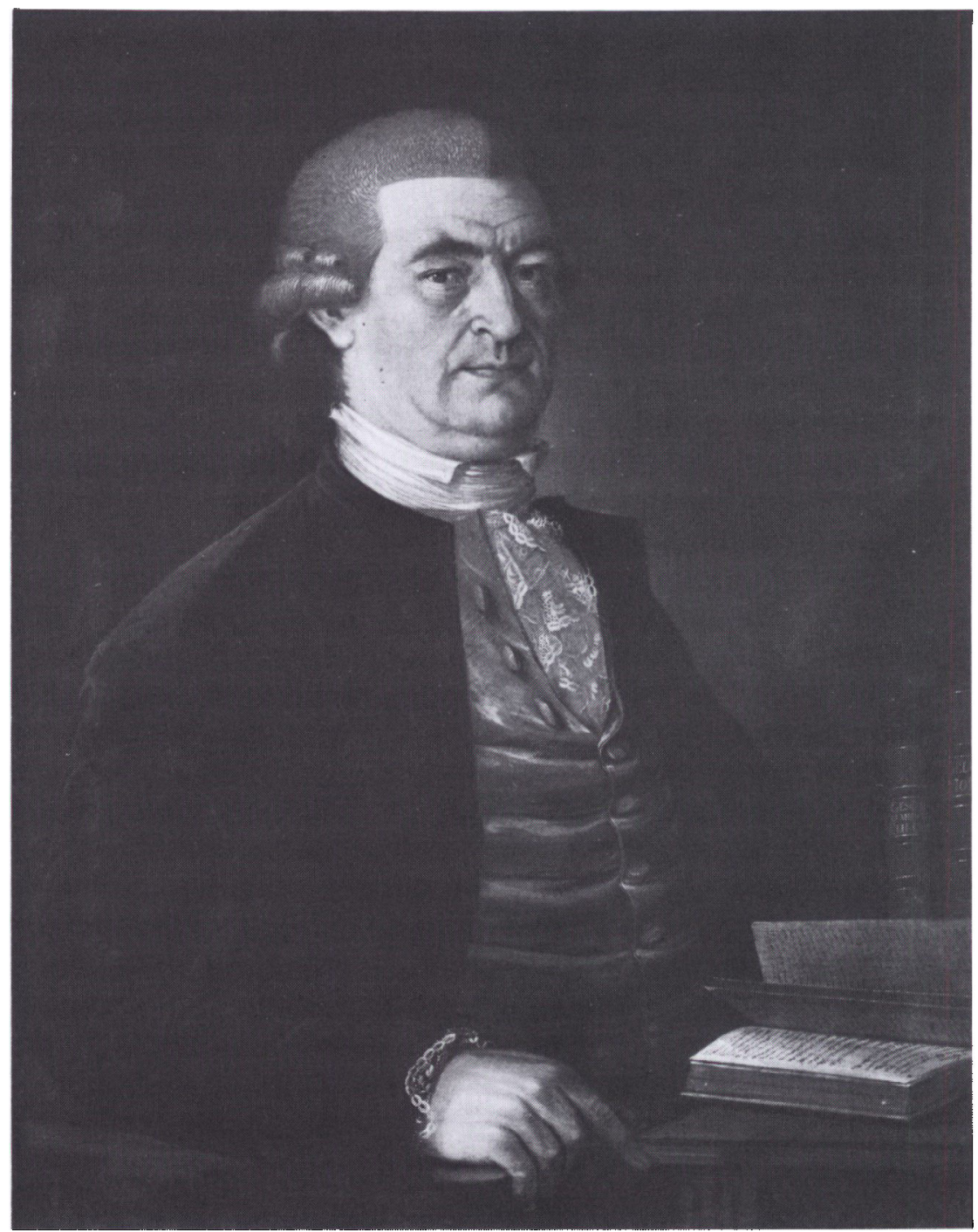

Kobmand Jacob Frederik Bjornsen (1739-1817) var i 1780'erne en af de rigeste købmand $i$ Aabenraa. Han havde investeret en del midler $i$ skibsanparter og var korresponderende reder for flere skibe. Desuden drev han en alsidig købmandshandel. Jes Jessen har malet billedet af den selvbevidste købmand i 1789. Billedet hanger i dag pả Städtisches Museum i Flensborg. Historiske Samlinger, Aabenraa.

Som det er fremgået af den ovenstående gennemgang, var Aabenraa i mange henseender et særtilfælde blandt de mindre byer i det danske monarki syd for Skagerrak. Ikke blot havde byen en betydelig handelsflåde $\mathrm{i}$ forhold til 
indbyggertallet, men dens beboere har også udvist et bemærkelsesværdigt initiativ ved at turde kaste sig så ensidigt ud i Middelhavsfarten og dermed i sejlads, der i samtiden må have indebåret langt større risici end den traditionelle småskibsfart til Norge og i de nærmestliggende dele af Østersøen.

Hvor succesfyldt denne specialisering har været, er det vanskeligt at vurdere, men sammenligner man de opgivne formuer ved den ekstraordinære skat $i$ 1789 med forholdene $i$ andre byer, giver det et fordelagtigt billede af Aabenraa. Mens der som vist i Aabenraa var fem købmænd med formuer på mindst 8.000 rigsdaler, var der i Odense, provinsens største by med dobbelt så mange indbyggere som Aabenraa, kun to købmænd over denne grænse. Tager man yderligere $\mathrm{i}$ betragtning, at skibsandelene var spredt ud på mange hænder, og at den slesvig-holstenske rigsdaler havde en større værdi end den danske, kan det være et tegn på, at handelsflåden har tjent mange penge hjem i de nærmest foregående år.

Skibene har også skabt mange arbejdspladser både om bord og $\mathrm{i}$ hjembyen, hvor der fandtes skibsværfter og anden udrustningsvirksomhed.

Selv om Aabenraas skibsfart målt med både før og senere var nede $i$ en bølgedal - vurderet ud fra flådens størrelse - har årene omkring år 1800 altså ikke betydet, at byen vendte søen ryggen.

\section{NOTER}

1. R. Romano: Per una valutazione della flotta mercantile Europea, i Studi in onore di Amintore Fanfani, 1962, side 573-91.

2. Eksempler på denne sejlads er omtalt i Lars N. Henningsen: Provinsmatadorer fra 1700-årene, 1985, s. 76-146 og i L. Beutin: Der deutsche Seehandel im Mittelmeergebiet, 1933.

3. Jf. Hans Chr. Johansen: Den danske skibsfart i sidste halvdel af det 18. århundrede, i Erhvervshistorisk Årbog 1975, side 62-89.

4. Otto Eck: Seeräuberei im Mittelmeer, 1943, side 189-243.

5. Efter at monarkiet havde afsluttet traktater med de nordafrikanske stater, skulle alle skibe inden afsejling til Sydeuropa løse et sådant pas, der over for sørøverskibe kunne bekræfte, at de var indregistreret i monarikiet.

6. Se om Aabenraa skibsfarts historie bl.a. H. Schlaikier: Aabenraa søfarts historie, 1929. Schiffahrt und Häfen, udgivet af Industrie- und Handelskammer zu Flensburg, 1971. F.H. Lassen: Aabenraa havns historie gennem 700 år, 1979. - Ole Mørkegaard m.fl.: Jørgen Bruhn, søfart og søfolk fra Aabenraa 1781-1858, i Sønderjysk Månedsskrift 1982.

7. også omtalt som en todæks hrekbord snav.

8. Af Aabenraaskibene, der sejlede ud med algierske pas i foråret 1785 , kom halvdelen hjem i løbet af sidste kvartal af 1785 eller i januar 1786 og næsten alle de øvrige i løbet af sommeren 1786. Kun to blev i Middelhavet indtil 1787.

9. Rigsarkivet, kommercekollegiet, 1773-97, nr. 1115ff.

10. Jf. Hans H. Worsøe (red.): Løjt sogns historie, 1988, side 166-76 (Carsten Porskrog Rasmussen). 